\title{
Collaborative Governance in Drug Prevention in Lhokseumawe, Indonesia
}

\author{
Aiyub $^{1}$ Sri Suwitri ${ }^{2}$ Endang Larasati ${ }^{3}$ Kismartini $^{4}$ \\ IPublic Administration Departement, Faculty of Social and Political Sciences, Diponegoro University, \\ Semarang, Indonesia \\ ${ }^{1}$ Faculty of Social and Political Sciences, Malikussaleh University, Lhokseumawe, Indonesia \\ ${ }^{2}$ Faculty of Social and Political Sciences, Tidar University, Magelang, Indonesia \\ ${ }^{3.4}$ Public Administration Departement, Faculties of Social and Political Sciences, Diponegoro University, \\ Semarang, Indonesia \\ *Corresponding author,Email:drs.aiyub@unimal.ac.id
}

\begin{abstract}
This study aims to examine the process of collaborative governance which has not been able to prevent the development of drug cases and its users in Lhokseumawe. A qualitative approach was used with in-depth interviews, observation, focus group discussion (FGD) and documentation as data collection methods. The data was analyzed qualitatively with an interactive model through the stages of data condensation, data display, and conclusions/verification. The results show that 1) face to face dialogue takes place openly, critically and constructively but still less intensive because there is no structured dialogue schedule 2) generally, trust building has high empathy by maintaining mutual respect for authority and respect for roles as loyalty and not building trust based on closeness and kinship, but based on regulatory demands. 3) commitment to process from stakeholders stated in the memorandum of understanding (MoU) has not been effective because there is no binding agreement (MoA) related to budget commitment which still has regulatory constraints and monitoring is dominantly carried out by related government. 4) shared understanding has no vision and mission in collaboration, only the vision and mission of BNN were carried out. 5) Positive intermediate outcomes are the existence of innovative programs and the birth of the draft Qanun on drug prevention while the negative impact is that the number of cases and drug users has not shown a decrease.
\end{abstract}

Keywords: Collaborative governance, Collaborative governance process, Drug prevention

\section{INTRODUCTION}

Collaborative governance is a collaboration between government and non-governmental stakeholders to solve public problems. Collaborative governance encourages joint efforts from government and non-governmental stakeholders to work together in overcoming complex problems through collective decision making.[1][2][3]. The implementation and collective decision-making is formal and consensus-oriented [4] including public issues related to drugs.

Why is collaborative governance needed in drug prevention? The answer is because the characteristics of drug problems are complex and cross-sector so that drug prevention requires the involvement of all parties (government, private and community). Referring to the Presidential Instruction of the Republic of Indonesia number 6 of 2018 as legal law, it is necessary to involve the entire stakeholders in implementing drug prevention. Thus, it is possible to have Regional Regulations, Governor Regulations, and Regent / Mayor Regulations to collaborate in implementing the drug prevention program [5] From preliminary data related to drug problems in Indonesia, it is known that none of districts and cities is free from drug problems [6]. National 
Narcotics Agency statistics show that in 2019 there were 654 drug-prone and vulnerable points in 34 provinces within Indonesia. Aceh Province ranks second with 64 drug-prone after Jakarta which ranks first with 117 points. The hot spots for drugs in Aceh are spread over 11 cities out of 23 cities, namely: Aceh Besar with 2 hot spots, Sabang City with 3 hot spots, Aceh Tamiang with 4 hot spots, Banda Aceh with 4 hot spots, South Aceh with 5 hot spots, Gayo Lues with 5 hot spots, Pidie Jaya with 5 hot spots, Langsa with 6 hot spots, Pidie with 6 hot spots, Bireun and Lhokseumawe with 12 hot spots [7].

The data above shows that Lhokseumawe and Bireun are the areas with the most drug-prone and vulnerable points among other cities in Aceh Province with 12 points. Having a look at the number of villages, it can be said that Lhokseumawe is the most drug-prone area compared to Bireun. Although both have 12 drugprone and vulnerable points, Lhokseumawe only has 68 villages while Bireun District has 609 villages. This means that there are more villages (17.64\%) prone and susceptible to drugs in Lhokseumawe compared to Bireun (1.97\%).

Lhokseumawe has a strategic location. As a transit city, it becomes the target for drug trafficking and becomes a gateway for drugs both by land and sea routes in Aceh [8]. Besides, Lhokseumawe is an open city so that drug abuse and trafficking spread easily. Hence, collaborative governance is needed to prevent drugs on all fronts.

Drug prevention that has been carried out so far has received positive appreciation from the community, but is also still receiving criticism regarding the commitment of Lhokseumawe government in providing support [8]. Appreciation and criticism arise because, on one hand, there are many drug prevention programs held each year, on the other hand, the number of cases and drug users keeps increasing. This indicates that collaborative governance in preventing the spread of drugs in Lhokseumawe has not been running optimally.

The results of document data tracing show that the number of drug cases in 2015 was: 62 cases, 2016 was 108 cases, 2017 was 123 cases, 2018 was 93 cases (end of August 2018 data) and 2019 was 105 cases [9]. These cases were reported by the users themselves or were reported by their families to the Lhokseumawe National Narcotics Agency from 2015 to 2019 totaling 538 users. Of these, 126 outpatient rehabilitated users and 103 hospitalized users [10]. This means that 229 drug users have not received rehabilitation.

The increase of cases and drug users in Lhokseumawe has a negative impact on future generations because drugs can destroy one's future in terms of physic and character. Drugs do not only threaten health but they also trigger the users to commit crimes. The absence of complete solution to solve drug problem will ruin the future of this country because drugs are far more virulent than cancer. Drugs do not just kill individuals, they kill people and generations. With such a terrible threat, an innovative idea is needed to prevent its spread by strengthening collaboration between stakeholders.

The increasing drug cases and users in Lhokseumawe is closely related to the prevention instrument, namely collaborative governance which is initiated by the parties. Therefore, the researchers attempted to examine the collaborative governance process of drug prevention from the dimensions of face to face dialogue, trust building, commitment to process, shared understanding and intermediate outcomes. The collaborative process is the main and important element believed to be able to 
determine the success or failure of collaborative governance in drug prevention in Lhokseumawe.

\section{METHODS}

This research is a qualitative study examining the process of collaborative governance in drug prevention in Lhokseumawe. The informants was selected purposively with certain considerations [11]. Informants were those knowing in-depth about the problems of this study so that accurate data and information could be obtained based on the facts from various parties involved. The informants were the Head of the BNNK, the Police, the Mayor, the Chairperson of the DPRK, the Chairperson of the MPU, the Head of the Immigration Office, the Head of Prisons, the Head of the Education and Culture Service, the Head of the Islamic Sharia Service, the Dean of the Unimal Faculty of Law, the Chairperson of the Anti-Narcotics Institute (LAN), the KNPI Chair, the Counselor Tabina Aceh-Lhokseumawe Foundation, Community Leaders, and Mayor's Experts who were involved in the process of drafting the Draft Qanun on Drug Prevention and Anti-Narcotics Curriculum. Data were collected through in-depth interviews, observation, FGD, and documentation. Furthermore, the collected data were analyzed by means of interactive qualitative analysis with three steps; data condensation, data presentation, and verification [12]. Then, the data was validated through triangulation techniques, technical triangulation techniques, and time triangulation.

\section{RESULTS AND DISCUSSION}

In collaborative governance, there are several main variables; the initial conditions, institutional design, leadership, and collaborative processes. The initial conditions, institutional design, and leadership are presented as supporters in order to make an important contribution to the collaboration process. While the process variables such as face to face dialogue, tust building, commitment to process, shared understanding, and intermediate outcomes are the core of the collaborative governance model [4].

\subsection{Face to Face Dialog}

The benchmark of face to face dialogue is whether the implementation of routine communication has been carried out. The routine communication is used to identify opportunities for mutual benefit among stakeholders. It is also used to identofy the quality of deliberation needs to pay attention to the effectiveness of existing communications in order to ensure that dialogue objectives can be achieved by holding open, critical, and constructive dialogue. There should be honesty and courage to express questions and disagreements as well as the existence of consensus-based decision-making in the discussion [4][13].

Face to face dialogue in the form of regular communication is important in collaboration, both in the form of formal and informal communication in order to facilitate the achievement of goals and reduce stereotypes and all problems that occur during the collaboration process. This study finds that communication in drug prevention collaboration was carried out formally through FGDs, coordination meetings, community meetings, work meetings and special meetings coordinated by the Mayor and BNN of Lhokseumawe as the leading sector. There was no intensive and structured dialogue schedule. This can impede drug prevention efforts as stakeholders rarely meet in a forum. Ansell and Gash [4] argues that the success of a collaborative process is reflected from good relationships between actors. Meanwhile, indirect relationship is carried out through social media such as Whatsapp, Twitter and Facebook which are managed by the National Narcotics Agency of 
Lhokseumawe. Good and effective communication will facilitate the building of trust and commitment as well as understanding between stakeholders to jointly achieve the goals of collaboration.

Face to face dialogue focusing on deliberation is reflected in open dialogue. Each stakeholder is given the opportunity to express opinion on drug problems and prevention strategies. Besides, in the implementation of critical dialogue, there should be time for questions and answers as well as bravery from dialogue participants to express opinions openly. The research findings show that face-to-face dialogue takes place openly to identify and anticipate the increasing drug trafficking at the village level, taking anticipatory steps and synergy between stakeholders, agencies, LRKM and LRIP in rehabilitation efforts for drug abusers. Anti-drug education is also included in the formal education curriculum, the need for a draft Qanun as well as on the Anti-Drug Curriculum, synergy across sectors, both with government agencies and BUMNs, and the need for each agency to form an anti-drug initiative to be able to independently carry out drug prevention.

In face-to-face dialogue, questions and answers were given and various criticisms emerged, especially against drug prevention programs which had so far been deemed ineffective and had not been able to reduce drug cases in Lhokseumawe. Likewise, in the context of whether or not the Qanun on drug prevention exists, there are differences of opinion and debate in the dialogue because they consider it too regulative and not substantive. Deliberation is conducted when there is something important to be decided together after which the stakeholders work separately within the scope of their respective duties. Sink in Dwiyanto [14] notes that in building collaboration is determined by consensus deliberation in order to achieve solutions and goals. Thus, collaboration cannot be achieved if it is done individually or separately.

Face to face dialogue is considered as efforts to find solutions together conveyed in a dialogue forum. The research findings indicate that there is a solution to the lack of budget and no optimal involvement from stakeholders in drug prevention programs. In terms of the minimum budget, the stakeholders have agreed to budget for their respective agencies, especially in the urine test and socialization program However, this has not been realized because there is no legal umbrella causing the obstruction of the implementation of the Narcotics prevention program. In terms of optimizing the involvement of stakeholders, the BNNK as the leading sector has tried to invite all components to be involved, from government, private sector, universities, media, NGOs, CSOs, and the community despite their minimum involvement.

\subsection{Trust Building}

Trust building is carried out since the collaborative process begins. The process of building trust between collaborative actors must focus on the experience of collaborating in the previous time. Whether it provides mutual benefit between parties or has negative impacts. Knowing and trusting one another is vital because there are relationships and interdependence based on tasks and roles [4][13].

The collaborative process of drug prevention in Lhokseumawe shows mutual trust among stakeholders in the experience of collaborating with other stakeholders. There is a prove that all agencies admit to having collaborated, both formally and incidentally, in the form of implementing joint activities by each stakeholder. Stakeholders generally have high empathy for 
fellow stakeholders because they think that collaboration has mutual benefits in making the community free from drugs. The difference in views of some stakeholders in seeing the importance of the Qanun on drug prevention does not diminish the enthusiasm of other stakeholders to create this Qanun. Currently, the Qanun on Drug Prevention has been included in the discussion agenda at DPRK Lhokseumawe.

It is necessary to maintain trust through mutual respect for each stakeholder and respect for the role of each stakeholder as the loyalty of stakeholders in order to gain benefit from the collaboration. It is found that what has been agreed upon has not all been complied with and there are no stakeholders violating it even though the stakeholders have a higher hierarchical level. This can happen because each stakeholder is in the same position. None has a function as a command but rather a coordination function that carries out their respective duties and responsibilities. Collaboration on drug prevention as a whole in the Lhokseumawe is coordinated by the Mayor/Deputy Mayor while implementation in the field is coordinated by BNNK as the leading sector.

Building trust in the context of social closeness should be stakeholdres' orientation to create emotional connection in drug prevention forming a sense of shared responsibility. Drugs are a complex problem and are not an individual problem, but a common problem. To prevent this, all components must be involved. The research finds that collaboration in drug prevention in Lhokseumawe was not based on social closeness and informal kinship, but based on regulatory demands on narcotics requiring the involvement of many parties in drug prevention. Informal faceto-face dialogue is considered important for identifying problems and building trust among stakeholders [15]. The intensity of face-to-face dialogue among stakeholders to discuss drug problems as a shared responsibility is still minimal showing that emotional relationships have not been well established in drug prevention collaborations.

\subsection{Commitment to Process.}

Commitment to this collaboration process can be seen from 1) Openness to exploring mutual gains by knowing the purpose of joining the collaboration, whether there are common interests (influenced by Face-to-Face Dialogue), 2) Mutual recognition of interdependence influenced by trust building indicator, 3) Shared ownership of process in the practice, influenced by other factors namely (1) incentive to boost motivation, and (2) challenges such as lack of funding and bad mutual trust, 4) the commitment is reflected in the presence of an optimistic attitude towards the achievement of collaboration goals and evidence of the commitment [4][13]. Commitment is closely related to original motivation to participate in collaborative governance.

Commitment to process is a critical component in the collaborative process as each stakeholder must be committed to do so. Commitment is an important factor in determining the success or failure of collaboration. According to Ansell and Gash [4], commitment to process is strong commitment from each stakeholder to prevent risks from the collaborative process. This study reveals that BNNK Lhokseumawe has asked every government and private sector to realize a commitment to the collaboration process by budgeting drug prevention funds in their respective agencies. This budget is useful for conducting urine tests for employees. However, most agencies have not budgeted the funds due to regulatory constraints, so urine tests cannot be carried out. 
In another context, there is a strong commitment in the collaborative process of drug prevention shown by the Lhokseumawe Police and the Indonesian Navy. During 2017-2019, police officers, TNI-AL elements, and local officials who were involved in drug problems were processed; the dismissal of 5 soldiers from the TNI-AL Base [16], the arrest of official who used crystal meth [17], the arrest of the Head of KIP Lhokseumawe [8] and the proposal for dismissal of a police officer in Lhokseumawe [8]. The commitment of the parties to the collaboration process is quite good and they have stated their commitment through the MoU because they think the drug problem is a common problem. The problem is how the commitment is realized in programs and activities that are currently considered less optimal and there are still those who have not taken part in the collaborative process of drug prevention. For example, the problem of commitment to budgeting for drug prevention in each government or private agency and financial support from the City Expenditure Budget (APBK) is available, but has not materialized so that the implementation is hampered.

Fail collaborations often lack long-term commitment by the stakeholders involved. In addition, commitment depends on mutual recognition which is the best way to respect perspectives and interests of other stakeholders in order to strengthen engagement among them. Mutual recognition is meant to be an agreement among collaborating stakeholders regarding roles and responsibilities carried out in drug prevention. This study reveals that mutual recognition of stakeholders does not have a document of division of tasks that is legally agreed upon, but only based on the general MoU emerged from face-toface dialogue. The MoU itself has not been going well because there is no agreement in detail in the form of an MoA. In addition, the draft Qanun has not been ratified so that the city government cannot allocate a budget for drug prevention specifically in the APBK without a legal protection.

Commitment to a process involves monitoring the development of drug abuse with various types and modes, and monitoring the results achieved in accordance with standards and consistency during the collaborative process in drug prevention in Lhokseumawe. In this context, the study finds that monitoring the results of collaborative drug prevention is more predominantly carried out by BNNK, Police, POM, Satpol PP / Wilayatul Hisbah, Team Star through joint raids on night entertainment venues, cafes in the KP-3 area, terminal, Cunda river bank, and a karaoke place on the main street. At the time of the raid, visitors were examined and urine tested. Meanwhile, Customs and TNI-AL, BNNK conducted joint patrols against drug smuggling both by land and sea, originating from various countries such as Malaysia, Thailand and China.

\subsection{Shared Understanding}

Shared understanding is an effort to identify common goals through an agreement on problems that must be resolved together, and also to unify vision, mission, and strategic direction based on mutual agreement to realize the ultimate goal of collaboration [4][13]. Common understanding is important in achieving common goals.

Matual understanding is crucial in achieving common goals. It is related to the same vision and mission, common goals, and objectivity. The stakeholders involved must develop consensus or shared understanding about the nature of the problem or, at least, about solutions to various views on the nature of the problem. Thus, they should agree on what they want to achieve 
together. Vision and mission are supporters of the success of a collaboration which only can be established when there is a common vision and mission.

In the collaboration of drug prevention in Lhokseumawe, there is no specific vision, mission and goals, but stakeholders support the vision, mission, and goals of the National Narcotics Agency as stipulated in the Head of the National Narcotics Agency Regulation No.7 of 2015 concerning the 2015 BNN Strategic Plan- 2019. The vision is to create free-drug environment in Indonesia. The mission is to unite and mobilize all the potential of society in efforts to prevent, rehabilitate, and eradicate drug abuse while the objective is to improve the prevention and eradication of drug abuse and trafficking.

Shared understanding of the vision, mission, and goals creates trust that can make stakeholders appreciate the differences that exist from other stakeholders. It is a condition in which all stakeholders agree on mutually agreed goals and values. The formation of shared understanding is often influenced by trust that has been formed in the collaboration. Ansell \& Gash [4] says that the stakeholders involved must share their understanding of what they can achieve through the collaboration. In practice, in Lhokseumawe, there is no shared vision and mission in collaboration, but only the vision and mission of BNN was carried out. Nonetheless, stakeholders still support the vision and mission of the National Narcotics Agency which is reflected in the achievements of various drug prevention programs as a result of interaction and sharing of understanding among stakeholders.

\subsection{Intermediate Outcome}

Intermediate outcome is the formation of tangible output in strategic plans (the work plan targets to achieve the right goals). It is important to build momentum that can produce successful collaboration result. There are more expected outcomes or field results (achievement of success, benefits) than what is not expected (failure and negative impact), whether planned or unexpected [4][13] . Intermediate outcomes generate feedback. The expected feedback is positive feedback called "small-wins" or any negative impacts that occur. Small-wins feed into the collaborative process fostering a virtuous cycle of building trust and commitment [18][3][4].

Intermediate outcomes generate feedback. In this case, it refers to the emergence of negative impacts and positive impacts in drug prevention collaborations. The expected feedback is positive one called "small-wins" or negative impacts. The research findings indicate that the intermediate outcome in drug prevention collaboration has a positive impact; 1) Through BNN Greeting program, Saweu Gampong, and Saweu Coffee Shop, community members have self-resistance to drug abuse; 2) Improving perceptions and participation of stakeholders in the implementation of the P4GN National Action Plan; 3) Increasing the involvement of the community, media, bloggers and millenials in drug prevention activities; 4) The establishment of an online media of anti-drug communication forum 5) Testing of saleum sikula program as pilot project. Meanwhile, the negative impact of collaborative drug prevention is not optimal which can be seen from the number of cases and drug users has not shown a decline each year.

\section{CONCLUSION}

From the discussion, it can be concluded that face to face dialogue has been running openly, critically and constructively, but is less intensive because there is no structured dialogue schedule. Yet, dialogue is generally carried out incidentally. Trust building can be seen from 
empathy, loyality, but social closeness and kinship has not been developed informally. The commitment to process from stakeholders is stated through the MoU, but it is not effective since there is no detailed binding agreement (MoA) related to the commitment to the drug prevention. The budget still has regulatory constraints, especially the draft of the Qanun on Drug Prevention which is currently still under discussion of City Representative Council (DPRK). Besides, the commitment to direct monitoring to the field in preventing drugs is still predominantly carried out by government agencies. Furthermore, there is still no a shared vision and mission, but only vision and mission of BNN which is carried out by stakeholders. Intermediate outcome in the form of positive impacts achieved through collaboration are the existence of innovative programs in drug prevention and the emergence of the draft Qanun on Drug Prevention, which after being passed will become the legal protection used by stakeholders in drug prevention. The negative impact can be seen from the number of cases and drug users every year which has not shown a decline because there are still unresolved inhibiting factors such as supporting regulations, binding agreements, and budgetary factors to finance drug prevention programs.

\section{REFERENCES}

[1] Gray, B. Collaborating: Finding Common Ground for Multiparty problems. San Francisco. Jossey-Bass. 1989. https://www.researchgate.net/publication/274752 166

[2] Bingham \& O'Leary, Public Managers in Collaboration in The Collaborative Public Manager; New Ideas for the twenty-firs century, Washinton DC; Georgetown University Press, 2008, ISBN 978-1-58901-223-3

[3] Huxham and Vangen. The Challenge of Collaborative Governance. Public Management, 2000.

http://dx.doi.org/10.1080/14719030000000 021
[4] Ansell, Chris and Alison Gash..Collaborative Governance in Theory and Practice, Journal of Public Administration Research and Theory, 2007 doi:10.1093/jopart/mum032

[5] http://bnn.go.id/rapimnas-bnn-2019

[6] Kompas.com,02/11/2017,indonesiadarurat-narkoba-sejak-1971 sampai sekarang https://regional.kompas.com

[7] National Narcotics Agency, 2019

[8] AJNN. net. Ketua KIP Lhokseumawe Ditangkap Karena Kasus Narkoba https://www.ajnn.net/news/ketua.01/04/2018

AJNN.net, Oknum Polisi Lhokseumawe Direkom Pecat Gunakan Narkoba https://www.ajnn.net/news/. 27/03/2019

-------AJNN.net, Lhokseumawe Target Peredearan Narkoba. https://www.ajnn.net/news

[9] Satres, Lhokseumawe Narcotics, 2019

[10] BNN Lhokseumawe, 2019

[11] Sugiyono. Metode Penelitian Kombinasi (Mix Methods), Cetakan ke 7, Alfabeta,CV,Bandung, 2015

[12] Miles, Huberman, Qualitatif Data Analysis, Third edition, SAGE Publication.Inc, 2014, ISBN 978-1-4522-5787-7

[13] Emerson , Kirk., Tina Nabatchi dan Stephen Balogh, Integrative Framework for Collaborative Governance', Journal of Public Administration Research and Theory,Vol. 22 no.1 . 2012, doi:10.1093/jopart/mur011

[14] Dwiyanto, A, Manajemen Pelayanan Publik, Inklusif, dan Kolaborasi. Yogyakarta: Gajamada Universitas Perss, 2015

[15] Bentrup, Gary. Evaluation of a collaborative model: A case study of analysis of watershed planning in the Intermountain West. Environmental Management, 2001. DOI: 10.1007/s002670010184

[16] Detik.com.Terlibat Narkoba, 5 Prajurit Pangkalan TNI AL Lhokseumawe Dipecathttps://news.detik.com/berita/d-3580775/. 31/072017

[17] Seruji.co.id. Polisi Lhokseumawe Tangkap Kadis Gunakan Sabu https://seruji.co.id/hukum/kriminal/polisi/20/04/2 $\underline{018}$

[18] Rogers, Todd, Beth Howard-Pitney, Ellen C. Feighery, David G. Altman, Jerry M. Endres, and April G.Roeseler. Characteristics and participant perceptions of tobacco control coalitions in California. Health Education Research, Theory \& Practice . 1993. 